\title{
Validation of the Wagnild and Young's Resilience Scale in adolescents in residential care
}

\author{
Validação da Resilience Scale de Wagnild e Young em contexto de acolhimento residencial de \\ adolescentes \\ Validación de la Resilience Scale de Wagnild y Young en el contexto de la acogida residencial \\ de adolescentes
}

Ana Maria Pacheco Mendes Perdigão Costa Gonçalves*; Ana Paula Camarneiro**

\begin{abstract}
Background: Residential care can protect adolescents by developing and maintaining their resilience.

Objective: To validate the Resilience Scale (RS), developed by Wagnild and Young (1993) and adapted to the Portuguese population by Felgueiras, Festas, and Vieira (2010), in a sample of adolescents in residential care.

Methodology: Methodological study on the validation of the RS, following a previous Portuguese adaptation, in a sample of 384 adolescents in residential care.

Results: The 25 -item RS had a high internal consistency $(\alpha=0.925)$. The exploratory factor analysis revealed a two-factor solution (personal competence and acceptance of self and life), which is in line with the original proposal. Some differences were found in item allocation. In adolescents, personal competence was positively and significantly correlated with age. Boys were significantly more resilient (total and dimensions) than girls. This difference was taken as discriminant validity.

Conclusion: This Portuguese version of the scale has many similarities with the original version but is different from the previously published Portuguese versions. It allows for the development of research on resilience in adolescents in residential care.
\end{abstract}

Keywords: resilience, psychological; validation studies; adolescent; institutionalization; nursing

\section{Resumo}

Enquadramento: $\mathrm{O}$ acolhimento residencial pode constituir proteção para os adolescentes, promovendo o desenvolvimento e manutenção da sua resiliência.

Objetivo: Validar, numa amostra de adolescentes em acolhimento residencial, a Resilience Scale (RS) de Wagnild e Young (1993), adaptada para português por Felgueiras, Festas, e Vieira (2010).

Metodologia: Estudo metodológico, de validação da RS, a partir de adaptação portuguesa prévia, numa amostra de 384 adolescentes em acolhimento residencial.

Resultados: A RS, de 25 itens, apresentou elevada consistência interna $(\alpha=0,925)$. A análise fatorial exploratória revelou uma soluçáo bifatorial (competência pessoal e aceitaçáo de si e da vida) de acordo com a proposta original. Algumas diferenças foram encontradas na alocaçáo de itens. Nos adolescentes, a competência pessoal foi positiva e significativamente correlacionada com a idade. Os rapazes são significativamente mais resilientes (total e dimensóes) do que as raparigas, diferença que foi tomada como validade discriminante.

Conclusáo: Esta versão portuguesa da escala tem muitas semelhanças com a versão original, distinguindo-se das versões portuguesas já publicadas. Permite a investigação sobre a resiliência em adolescentes em acolhimento residencial.

Palavras-chave: resiliência psicológica; estudos de validação; adolescente; institucionalização; enfermagem

*MSc., Adjunct Professor, Nursing School of Coimbra, 3046-851, Coimbra, Portugal [aperdigao@esenfc.pt]. Contribution to the article: study design, subject recruitment, data collection, literature search, elaboration of the literature review text and discussion of results, article writing. Address for correspondence: Avenida Urbano Duarte, $n^{\circ} 84,3^{\circ}$ Esquerdo, 3030-215, Coimbra, Portugal

**Ph.D., Adjunct Professor, Nursing School of Coimbra, 3046-851, Coimbra, Portugal [pcamarneiro@esenfc.pt].Contribution to the article: guidance of the study design, literature search and statistical analysis, critical revision of the manuscript, article writing

\section{Resumen}

Marco contextual: La acogida residencial puede constituir protección para los adolescentes, lo que promueve el desarrollo y mantenimiento de su resiliencia.

Objetivo: Validar, en una muestra de adolescentes en acogida residencial, la Resilience Scale (RS) de Wagnild y Young (1993), adaptada al portugués por Felgueiras, Festas, y Vieira (2010).

Metodología: Estudio metodológico de validación de la RS a partir de la adaptación portuguesa previa en 384 adolescentes en acogida residencial.

Resultados: La RS, de 25 ítems, presenta elevada consistencia interna $(\alpha=0,925)$. El análisis factorial exploratorio sugirió una solución bifactorial (competencia personal y aceptación de sí mismo y de la vida), de acuerdo con la propuesta original, y muestra algunas diferencias en la asignación de los ítems. En los adolescentes, la competencia personal se correlaciona positiva y significativamente con la edad. Los chicos son significativamente más resilientes (total y dimensiones) que las chicas, diferencia que fue tomada como validez discriminante.

Conclusión: Esta versión portuguesa de la escala tiene muchas similitudes con la versión original aunque se distingue de las versiones en portugués anteriormente publicadas. Permite la investigación sobre la resiliencia en adolescentes en acogida residencial.

Palabras clave: resiliencia psicológica; estudios de validación; adolescente; institucionalización; enfermería

Received for publication: 02.10 .17

Accepted for publication: 08.03.18 


\section{Introduction}

Based on the published evidence, resilience is defined as a positive characteristic that promotes individual adaptation and moderates the negative effects of stress (Wagnild \& Young, 1993), allowing the individuals to develop positively when exposed to situations of adversity. Authors such as Masten (2009) believe that resilience increases in the individual's interaction with the environment, promotes well-being, and protects the individual from being subjugated by the risk factors.

Research on resilience has more than two decades and has been developed in different contexts and age groups. However, according to Cordovil, Crujo, Vilariça, and Caldeira da Silva (2011), it "only makes sense when applied to populations considered at risk which, simultaneously, present adaptive attributes. That is what we find in Child and Adolescent Residential Institutions" ( $p$. 413). Adolescent residential care is a significant life transition which usually results from traumatic situations involving personal, social, and family risk and/or the family's inability to ensure a healthy development.

Although residential care ca be an undesirable transition for adolescents, causing a sense of loss (Cordovil et al., 2011) and conditioning their emotional development, it may be, despite its non-familial structure, a situation of protection against the difficulties encountered within the family (Poletto \& Koller, 2008) and promotion of resilience.

Studies on resilience represent an approach to the knowledge about the development of children and adolescents when confronted with adverse circumstances. Thus, due to the lack of studies on this field, research on resilience is of utmost importance, particularly its assessment using appropriate and validated tools for specific populations such as young people in residential care. This study aims to validate the 25 -item Resilience Scale (RS), developed by Wagnild and Young (1993) and adapted to the Portuguese population by Felgueiras, Festas, and Vieira (2010), in a sample of adolescents in residential care.

\section{Background}

Resilience continues to be an object of study due to its potential impact on health, well-being, and quality of life. In spite of the studies carried out over the last decade, the concept of resilience has no consensual definition and its assessment in adolescents, when compared to its assessment in adults, it still an understudied area with inconsistent results (Pinheiro \& Matos, 2013). According to Rutter (1993), resilience involves social and intra-psychic processes which are in constant transformation and promote, for example, a healthy life, even within a non-healthy environment. Rutter (2006) also underlines that resilience results from the combination of the child/adolescent's characteristics and their family, social, and cultural environment and that it is not an intrinsic trait, but rather results from the interaction between the individual and the environment. It mainly concerns the dynamic processes between risk factors and protective factors which promote positive long-term effects on development.

From the point of view of adolescence, resilience is usually seen as the demonstration of competence in an adverse environment, a response to risk, which may be affected by conditions of poverty, family ruptures, experience of some type of violence, experiences of illness (in the adolescent or family), and important losses (Pesce, Assis, Santos, \& Oliveira, 2004).

According to Koller, Cerqueira-Santos, Morais, Ribeiro, and Martiniano (2004), when adolescents' need for residential care results from traumatic situations involving personal, social, and family risk, the removal from the family can be perceived as a rejection, which is not always accepted by the adolescent in a period of major internal and external changes, identity formation, and acquisition of the ability to cope with adversities. However, Yunes and Szymanski (2001) believe that negative life experiences are perceived and interpreted differently by different individuals and, from this perspective, it is interesting to note that young people are sometimes capable of establishing lasting emotional connections with alternative figures in new contexts, although the residential care process has a significant emotional impact on development. In adolescent residential care, resilience involves an interaction between risk factors, protective factors, and the type of in- 
tervention which is offered to the adolescent (Guilera, Pereda, Paños, \& Abad, 2015).

Institutional care, which is now called residential care (Lei n. ${ }^{\circ}$ 142/2015, 8 de setembro, p. 7204),

consists of placing the child or young person in the care of an institution that has facilities, equipment, and permanent human resources, duly qualified, to ensure their adequate assistance.

Residential care aims to contribute to the creation of conditions which ensure the proper satisfaction of children and young people's physical, mental, emotional, and social needs and the effective exercise of their rights, promoting their integration into a safe social-family environment, their education, well-being, and full development.

As an intervention offered to adolescents, residential care is not in itself a risk factor for their development because the organization and structure of these facilities, although they can be considered as high-risk environments, promote human development and, at a given moment, they may be the only source of social and emotional support to cope with adversity (Siqueira \& Dell'Aglio, 2006). In residential care, adolescents can establish meaningful emotional connections in the new context, thus reducing the risk factors associated with this transition. Mota and Matos (2010) consider that these young people's development can be influenced by other significant figures who can give them high-quality personal, emotional, and social responses, enabling an adaptive development.

In addition, according to Poletto and Koller (2008), the social and emotional support network, as a protective structure, triggers resilience processes which promote a positive attitude in adolescents, showing them the possibility to build new paths, resuming their development from the rupture, and finding themselves again (Siqueira \& Dell'Aglio, 2006).

Resilience can be the key to explaining the resistance to risk and how people overcome and cope with the challenges throughout their life cycle (Windle, Bennet, \& Noyes, 2011).

\section{RS - original version}

Although research on resilience has little more than two decades and its practical application is even more recent, it is an important factor for health, well-being, quality of life, and response to challenges throughout the lifecycle (Pinheiro \& Matos, 2013).

Wagnild and Young (1993) developed the RS and assessed its psychometric properties with the purpose of identifying the degree of individual resilience, which is considered by the authors as a positive personality characteristic that enhances individual adaptation. These authors conducted a qualitative study in which they interviewed 24 adult women who had adapted successfully to situations of vulnerability. Five themes emerged from these interviews: equanimity; perseverance; self-reliance; meaningfulness; and existential aloneness, which influenced the development of the scale items.

The scale was made available and pre-tested in 1988 and published in 1990. Later on, it was tested in larger $(N=880)$ and diversified samples, in line with the theoretical construct described in the literature in the area of Philosophy and Psychology (Wagnild \& Young, 1993). The scale is composed of 25 items rated on a 7 -point Likert scale ranging from 1 , strongly disagree, to 7 , strongly agree. Scores varied between 25 and 175, with the highest scores indicating higher resilience.

The mean score for the RS was 147.91 (SD =16.85). Scores between 145 and 175 were considered high, being on the line between high and mid-range scores. The authors found no significant correlations between the RS and age, education, income, and gender. The reliability of the scale was high, with a Cronbach's alpha of 0.91 , and the corrected item-total correlations ranged from 0.37 to 0.75 , with the majority of them scoring between 0.50 and 0.70 .

With regard to validity, the principal components analysis (PCA) with varimax rotation revealed five components. However, the scree plot showed a cutoff point between factors 1 and 2 and the remaining factors, and the factor solution indicated two major factors. Based on these results, Wagnild and Young (1993) decided to use the two-factor solution, with loadings above 0.40 for each 
item, considering that they reflected the theoretical definition of resilience and supported the construct validity of the RS. Factor 1 is composed of 17 items $(1,2,3,4,5,6,9,10$, $13,14,15,17,18,19,20,23$, and 24) and corresponds to the personal competence; Factor 2 is composed of eight items $(7,8,11$, $12,16,21,22$, and 25) and corresponds to the acceptance of self and life. According to the authors, factor 1 measures self-reliance, independence, determination, invincibility, mastery, resourcefulness, and perseverance. Factor 2 measures adaptability, balance, flexibility, and a balanced perspective of life. Both factors explain $44 \%$ of the total variance.

This instrument has been applied to a variety of groups, with different ages and in different contexts. It is translated into several languages, including to Brazilian and European Portuguese (Pinheiro \& Matos, 2013).

Portugal currently has two versions: a long, 25 -item version, and a short, 14 -item version, both validated for the population of adolescents by Felgueiras et al. (2010) and Oliveira, Matos, Pinheiro, and Oliveira (2015), respectively. However, the instrument is not exempt from criticism, namely concerning its application in adolescents. These criticisms recommend more rigor in content validity. Nevertheless, this instrument has the highest scores in terms of total quality, it was the first tool developed to analyze resilience, and it continues to be one of the most widely used tools in research (Pinheiro \& Matos, 2013). In addition, Ahern, Kiehl, Sole, and Byers (2006) concluded that this scale, due to its psychometric characteristics and properties, is the most suitable instrument for studying resilience in the adolescent population.

\section{RS - Portuguese versions}

The Portuguese version by Felgueiras et al. (2010) proved to be a reliable, valid, and sensitive instrument which, according to the authors, can be used by nurses or other professionals to measure resilience, particularly in children and adolescents. The authors sought to preserve the 25 items, keeping their original meaning; however, in the homogeneity study, item 5 was deleted due to its low correlation $(<0.20)$ and the increase in Cronbach's alpha if this item was deleted.
The internal consistency of the remaining 24 items was $\alpha=0.82$. Five main components emerged from the PCA, explaining $46.04 \%$ of total variance. The authors pointed out that because items $6,11,15$, and 17 loaded on more than one factor, generating ambiguity in interpretation, they decided to associate the item to the factor in which it had higher factor loading (items 6 and 15). With regard to items 11 and 17 , they decided to associate them with the factor in which they had a higher factor loading and where they would be more interpretable. The validation study showed that the scale had discriminant validity, good temporal stability, and good conceptual equivalence.

In 2013, in a sample of 180 adolescents, Pinheiro and Matos explored the construct validity of the version translated into Portuguese by Felgueiras et al. (2010), in which the items were adapted to the Portuguese grammar. In the PCA, with the Kaiser-Meyer-Olkin measure $(\mathrm{KMO}=0.927)$, Bartlett's test of sphericity, with $p \leq 0.001$ and commonalities $>0.495$, the authors found a five-factor solution, explaining $64.2 \%$ of the variance and initial eigenvalues greater than 1. All items (except items 13 and 20) had high factor loadings on the first factor ( 0.520 to 0.756$)$, which explained $43 \%$ of total variance. However, based on the scree plot, the authors decided to retain a single factor. Another PCA, with 23 items (excluding items 13 and 20) and a single-factor structure, explained $46 \%$ of the total variance. The items' factor loadings ranged from 0.518 (item 19) to 0.804 (item 1) and the Cronbach's alpha for the total scale was 0.945 . These results are not consistent with the first validation for Portuguese or with the original version, corroborating some of the criticisms on the use of the scale in adolescents and indicating the need for further validation studies.

\section{Research question}

Does the RS developed by Wagnild and Young (1993) and adapted to Portuguese by Felgueiras et al. (2010) have good psychometric properties in adolescents in residential care? 


\section{Methodology}

A quantitative, descriptive, methodological study was conducted to validate the long, 25item version of the RS developed by Wagnild and Young (1993) using a non-probability sample of 384 adolescents living in residential care in several regions in the north, center, and south of Portugal. This validation was performed based on the adaptation to Portuguese by Felgueiras et al. (2010) after permission was requested from the authors to use the scale. Both the scale and a sociodemographic characterization questionnaire were applied at the residential care facilities. All ethical principles were met. After approval by the Ethics Committee of the Health Sciences Research Unit: Nursing, of the Nursing School of Coimbra, a request was sent to the director of each of the institutions selected in the north, center, and south regions of Portugal. Each director was responsible for obtaining the authorizations for each minor. Data were analyzed using IBM SPSS Statistics software, version 22.

In the psychometric study, both reliability and construct validity were analyzed. In the latter, an exploratory factor analysis was performed using the PCA followed by orthogonal varimax rotation, making these solutions interpretable. The Kaiser-Meyer-Olkin measure and Bartlett's test of sphericity were previously calculated.

The decision on the number of factors to retain in the analysis was based on eigenvalues greater than 1 . The choice of the factor solutions followed the criterion of item-factor convergent validity, with each item showing a factor loading greater than 0.40 . It also complied with the criterion of item-factor discriminant validity, in which the items with factor loadings lower than 0.40 should not load on the factor. Finally, it also complied with the principle that the final solution must explain more than $40 \%$ of the total variance and that there must be a match between the theoretical structure and the factor structure. With regard to reliability, the homogeneity and internal consistency of the items for the total scale and its dimensions were analyzed. The internal consistency coefficient (Cronbach's alpha) and the corrected item-total correlation coefficient were calculated. Finally, summary statistics, descriptive statistics, and inferential statistics of mean differences for gender and correlations for age, education, and length of stay in residential care were calculated.

\section{Results}

The sampled adolescents were aged between 10 and 19 years $(M=14.77 ; S D=2.07)$. They had been in residential care facilities for 1 to 229 months $(M=39.71 ; S D=38.14)$. Girls represented $64.1 \%$ and boys $35.9 \%$ of the sample. Their education level ranged from 3 to 12 years $(M=7.77, S D=1.95)$. Most of them attended the $9^{\text {th }}$ grade $(25.4 \% ; n=96)$, which was expected based on their mean ages. With regard to internal consistency, the psychometric analysis revealed a high Cronbach's alpha of 0.925 for the 25 items, rated on a Likert scale from 1 to 7 . The corrected item-total correlation ranged from 0.405 to 0.707 , with the exception of item 11 , "I seldom wonder what the point of it all is", with a correlation of 0.386 , and item 20, "Sometimes I make myself do things whether I want to or not", with a correlation of 0.267 . Cronbach's alpha coefficient would not increase if any other item was deleted (Table 1). Furthermore, the content of the scale items was considered appropriate. 
Table 1

Internal consistency of the $R S$

\begin{tabular}{|c|c|c|}
\hline Scale items & $\begin{array}{l}\text { Corrected item-total } \\
\text { correlation }\end{array}$ & $\begin{array}{c}\text { Cronbach's alpha if item } \\
\text { deleted }\end{array}$ \\
\hline 1 & 0.579 & 0.918 \\
\hline 2 & 0.551 & 0.919 \\
\hline 3 & 0.639 & 0.917 \\
\hline 4 & 0.530 & 0.919 \\
\hline 5 & 0.457 & 0.920 \\
\hline 6 & 0.606 & 0.918 \\
\hline 7 & 0.666 & 0.917 \\
\hline 8 & 0.614 & 0.918 \\
\hline 9 & 0.600 & 0.918 \\
\hline 10 & 0.599 & 0.918 \\
\hline 11 & 0.386 & 0.922 \\
\hline 12 & 0.503 & 0.920 \\
\hline 13 & 0.491 & 0.920 \\
\hline 14 & 0.540 & 0.919 \\
\hline 15 & 0.613 & 0.918 \\
\hline 16 & 0.488 & 0.920 \\
\hline 17 & 0.691 & 0.916 \\
\hline 18 & 0.615 & 0.918 \\
\hline 19 & 0.612 & 0.918 \\
\hline 20 & 0.267 & 0.924 \\
\hline 21 & 0.495 & 0.920 \\
\hline 22 & 0.405 & 0.922 \\
\hline 23 & 0.629 & 0.917 \\
\hline 24 & 0.707 & 0.916 \\
\hline 25 & 0.487 & 0.920 \\
\hline
\end{tabular}

With regard to construct validity, the Kaiser-Meyer-Olkin $(\mathrm{KMO}=0.931)$ measure and Bartlett's test of sphericity $\left(\mathrm{x}^{2}=3857.383\right.$; $p<0.001)$ were previously calculated, followed by the exploratory factor analysis using the principal components method with orthogonal varimax rotation and Kaiser normalization. Commonalities were lower than 1 . A five-factor solution was found with eigenvalues greater than 1, which explained 56\% of the variance. However, the analysis of the percentage of variance of the initial eigenvalues for each of the factors and the scree plot showed that the cutoff point was on factor 2 , which is consistent with the results of the original scale developed by Wagnild and Young in 1990 (Wagnild \& Young, 1993). In addition, item distribution across the factors resulted in a limited number of items, 2 and 3 items, respectively, for factors 3 and 4 .

According to the proposal of the authors of the original scale, assuming that the percentage of variance would be higher than $5 \%$ for each component, the study was conducted using 4 and 3 factors, resulting in the decision to assume a two-factor solution. The scree plot showed that the two-factor solution was the most appropriate solution (Figure 1). 


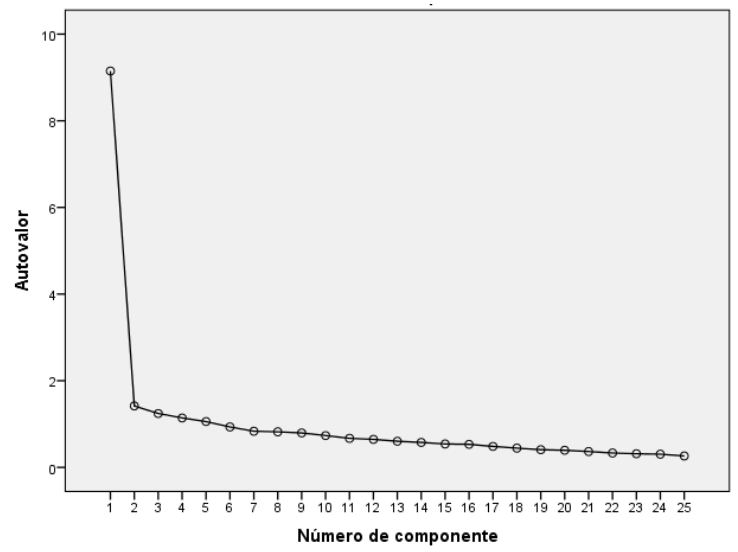

Figure 1. Scree plot for the RS.

In view of the results obtained and the analysis of the scree plot in Figure 1, as well as in line with the original proposal, a two-factor solution was used which was obtained through the PCA with varimax rotation and Kaiser normalization. The total variance explained was $42.3 \%$ (22.7\% in factor 1 and $19.6 \%$ in factor 2). Initial eigenvalues explained $36.6 \%$ of the variance in factor 1 and $5.7 \%$ in factor 2 . Below these, all values were lower than $5 \%$.

Item distribution across the components was based on factor loadings. Loadings above 0.40 and that that did not load on both components were accepted. Factor 1 - personal competence
(PCOM) - was composed of 11 items $(1,3,5,9$, $10,13,14,18,19,20,25)$, with loadings ranging from 0.433 (item 25 ) to 0.738 (item 3 ). This factor had a good internal consistency $(\alpha=0.851)$. Factor 2 - acceptance of self and life (ACCEPSL) - was composed of 14 items. The corrected item-total correlation ranged from 0.453 (item 22) to 0.772 (item 21). This factor also had a high internal consistency $(\alpha=$ 0.890 ; Table 2).

Indeed, the distribution of these items was somehow different from the original proposal for item distribution but was in line with the factor analysis and the content analysis.

Table 2

Factor structure of the $R S$ and internal consistency of the factors

\begin{tabular}{lllcc}
\hline & $\begin{array}{c}\text { No. of } \\
\text { Factors }\end{array}$ & Items & $\begin{array}{c}\text { Factor } \\
\text { loading } \\
\text { F1 }\end{array}$ & $\begin{array}{c}\text { Factor } \\
\text { loading }\end{array}$ \\
\hline F2
\end{tabular}




\begin{tabular}{|c|c|c|c|c|}
\hline \multirow{14}{*}{ 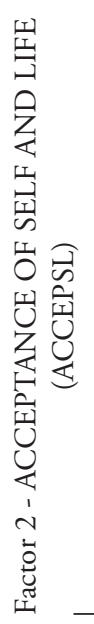 } & 21 & My life has meaning & -0.043 & 0.772 \\
\hline & 17 & My belief in myself gets me through hard times & 0.406 & 0.623 \\
\hline & 23 & When I'm in a difficult situation, I can usually find my way out of it & 0.320 & 0.622 \\
\hline & 6 & I feel proud that I have accomplished things in life & 0.278 & 0.621 \\
\hline & 8 & I am friends with myself & 0.295 & 0.620 \\
\hline & 24 & I have enough energy to do what I have to do & 0.433 & 0.613 \\
\hline & 2 & I usually manage one way or another & 0.267 & 0.577 \\
\hline & 4 & Keeping interested in things is important to me & 0.229 & 0.573 \\
\hline & 7 & I usually take things in stride & 0.434 & 0.561 \\
\hline & 16 & I can usually find something to laugh about & 0.202 & 0.542 \\
\hline & 11 & I seldom wonder what the point of it all is & 0.053 & 0.528 \\
\hline & 15 & I keep interested in things & 0.434 & 0.506 \\
\hline & 12 & I take things one day at a time & 0.289 & 0.479 \\
\hline & 22 & I do not dwell on things that I can't do anything about & 0.267 & 0.453 \\
\hline & & Alpha of Factor $2=0.890$ & & \\
\hline
\end{tabular}

The analysis of the descriptive data of total resilience (TR) and its dimensions (Table 3) showed that young people's resilience levels were, on av- erage, $129.42(S D=24.77)$, ranging from 39 to 175. The mean of each item was 5.18, ranging from $4.38(S D=1.895)$ to $5.79(S D=1.651)$.

Table 3

Descriptive results of the $R S$ and its dimensions

\begin{tabular}{lccccc}
\hline RS & $N$ & Min. & Max. & $M$ & $S D$ \\
\hline TR & 384 & 39 & 175 & 129.42 & 24.77 \\
PCOM & 384 & 12 & 77 & 56.36 & 11.74 \\
ACCEPSL & 384 & 20 & 98 & 72.95 & 14.82 \\
\hline
\end{tabular}

Note. Min. $=$ Minimum $;$ Max. $=$ Maximum,$M=$ Mean $; S D=$ Standard deviation .

With regard to age, a positive and significant correlation was found between age and the dimension PCOM. No other significant cor- relations were found between resilience and education and between resilience and length of stay in residential care (Table 4).

Table 4

Pearson's correlation of the $R S$ and dimensions with age, education, and length of stay in residential care

\begin{tabular}{lcccccc}
\hline RS $(N=384)$ & \multicolumn{2}{c}{ Age } & \multicolumn{2}{c}{ Education } & \multicolumn{2}{c}{ Length of stay in residential care } \\
\hline \multirow{2}{*}{ TR } & $r$ & $p$ & $r$ & $p$ & $r$ & $p$ \\
\cline { 2 - 7 } PCOM & 0.046 & 0.373 & -0.002 & 0.970 & 0.003 & 0.948 \\
ACCEPSL & 0.105 & 0.040 & 0.046 & 0.378 & -0.026 & 0.609 \\
\hline
\end{tabular}

The analysis of the distribution according to gender showed that boys had higher mean scores than girls in TR $(M=140.80$; $S D=20.55$ and $M=123.11 ; S D=24.69$, respectively) and in the dimensions PCOM $(M=60.77 ; S D=10.24$ and $M=53.93 ; S D$ $=11.83$, respectively $)$ and ACCEPSL $(M=$ 80.04; $S D=11.78$ and $M=69.06 ; S D=$ 
14.89 , respectively). The Student's t-test for independent samples confirmed that these differences were significant, both in TR $(t=-7.128$; $p<0.001)$ and in the dimensions $\operatorname{PCOM}(t=-$ 5.694; $p<0.001)$ and ACCEPSL $(t=-7.959$; $p<0.001$; Table 5).

Table 5

Student's t-test for mean comparison in the RS and dimensions according to gender

\begin{tabular}{lcccccccc}
\hline$R S$ & Gender & $N$ & Min. & Max. & $M$ & $S D$ & $t$ & $p$ \\
\hline \multirow{2}{*}{ TR } & $\mathrm{F}$ & 247 & 39 & 172 & 123.11 & 24.69 & -7.128 & 0.001 \\
& $\mathrm{M}$ & 137 & 93 & 175 & 140.80 & 20.55 & & \\
\multirow{2}{*}{ PCOM } & $\mathrm{F}$ & 247 & 12 & 76 & 53.92 & 11.83 & -5.694 & 0.001 \\
& $\mathrm{M}$ & 137 & 37 & 77 & 60.77 & 10.24 & & \\
\multirow{2}{*}{ ACCEPSL } & $\mathrm{F}$ & 249 & 20 & 96 & 69.06 & 14.89 & -7.959 & 0.001 \\
& $\mathrm{M}$ & 137 & 50 & 98 & 80.04 & 11.78 & & \\
\hline
\end{tabular}

Note . Min. = Minimum; Max. = Maximum; $M=$ Mean; $S D=$ Standard deviation .

\section{Discussion}

In this study, with a specific sample of adolescents in residential care, the results showed that these young people's resilience levels $(M=129.42 ; S D=24.77)$ were higher than those found by Felgueiras et al. (2010; $M=$ 126.66) and lower than those found by Wagnild and Young (1993) in the original study $(M=147.91 ; S D=16.85)$. These authors considered that scores above 145 were high and that there can be some influence of the cultural context in lower scores, as it is the case in the Portuguese samples. In the sample under analysis, residential care may have hindered resilience due to the unwanted transition or the potential feeling of loss (Cordovil et al., 2011). In a clinical sample, Pinheiro and Matos (2013) found a mean of 119.81 using the long version of the scale but with only 23 items. Despite this, these scores are lower than those found in this study with adolescents in residential care.

In relation to the psychometric properties, reliability was high in this study, with a Cronbach's alpha of 0.925 and corrected item-total correlations ranging from 0.405 to 0.707 , with most of them ranging from 0.50 to 0.70 , which are very close to the scores obtained by Wagnild and Young (1993; $\alpha=0.91)$ and Pinheiro and Matos $(2013 ; \alpha=0.945)$. The study of Felgueiras et al. (2010) found a lower internal consistency using a 24 -item version $(\alpha=0.82)$.
The construct validity of this sample was similar to the original two-factor version proposed by Wagnild and Young (1993). The Portuguese studies propose another type of factor solution. For example, Felgueiras et al. (2010) proposed five dimensions and Pinheiro and Matos (2013) proposed a single-factor solution.

Despite the similarity with the two-factor solution, the items in each factor do not match completely in both studies. In the original study, factor 1 is composed of 17 items $(1,2,3,4,5,6,9,10,13,14,15,17$, $18,19,20,23$, and 24), which correspond to the personal competence, whereas in this study the same factor is composed of 11 items $(1,3,5,9,10,13,14,18,19,20$, and 25).

In the original study, factor 2 is composed of eight items (7, 8, 11, 12, 16, 21, 22, and 25), corresponding to the acceptance of self and life, whereas in this study it is composed of 13 items $(2,4,6,7,8,11,12,15,16,17,21$, and 22), also corresponding to the acceptance of self and life. These differences may be due to cultural issues or sample specificity because they make sense in terms of construct and content validity.

In this study, the results showed a correlation between age and personal competence, with older participants being more able to cope with situations of adversity, and differences in resilience according to gender, with boys being more resilient than girls. Wagnild and 
Young (1993) found no significant correlations between RS and age, education, income, and gender, unlike the results obtained here. According to Pesce et al. (2004), the social and emotional support provided by residential care can act as a facilitator in adolescents' individual process of understanding and coping with high risk situations, making them resilient; however, resilience is sensitive to the length of stay in residential care, reinforcing the idea, for example, that its development is immediate in case of institutionalization.

\section{Conclusion}

This study with adolescents in residential care showed good psychometric properties and a two-factor solution of the RS of Wagnild and Young (1993), as proposed by the authors in the original study. Despite this similarity, some inconsistencies were found in the item distribution across the factors, which reinforces the inconsistencies found in earlier studies conducted with adolescents. Cultural reasons, more than sample specificity, may explain these results because residential care does not in itself pose a risk for development.

Resilience seemed to be a characteristic of the young people in this study because the mean scores, although below those found by Wagnild and Young (1993), were similar to those found by Felgueiras et al. (2010) and higher than those found by Pinheiro and Matos (2013). In addition, PCOM increased with age, boys were more resilient than girls in TR, PCOM, and ACCEPSL, and resilience was not sensitive to education or length of stay in residential care.

This study has further contributed to the validation of the scale, confirming the possibility of using it in adolescents in residential care. Given the differences found in the several validation studies with adolescents in Portugal, new adaptations and new validation studies will be useful contributions to the further analysis of the original scale and its dimensions.

\section{References}

Ahern, N. R., Kiehl, E. M., Sole, M. L., \& Byers, J. (2006). A review of instruments measuring resilience. Issues in Comprehensive Pediatric Nursing, 29(2), 103125. doi: 10.1080/01460860600677643

Cordovil, C., Crujo, M., Vilariça, P., \& Caldeira da Silva, P. (2011). Resiliência em crianças e adolescentes institucionalizados. Acta médica portuguesa, 24(S2), 413-418. Retrieved from https://actamedicaportuguesa.com/revista/index.php/amp/article/ viewFile/1473/1059

Felgueiras, M. C., Festas, C., \& Vieira, M. (2010). Adaptação e validação da Resilience Scale de Wagnild e Young para a cultura portuguesa. Cadernos de saúde, 3(1), 73-80.

Guilera, G., Pereda, N., Paños, A., \& Abad, J. (2015). Assessing resilience in adolescence: The Spanish adaptation of the Adolescent Resilience Questionnaire. Health and Quality of Life Outcomes, 11(13), 100. doi: 10.1186/s12955-015-0259-8

Koller, S. H., Cerqueira-Santos, E., Morais, N. A., Ribeiro, J., \& Martiniano, G. (2004). Juventude brasileira em situação de risco social e pessoal: Projecto de pesquisa inédito. Porto Alegre, Brasil: Universidade Federal do Rio Grande do Sul.

Lei n. ${ }^{o}$ 142/2015 de 8 de Setembro. Diário da República $n^{o}$ 175/2015 - 1a Série. Assembleia da República. Lisboa, Portugal.

Masten, A. S. (2009). Ordinary magic: Lessons from research on resilience in human development. Education Canada, 49(3), 28-32. Retrieved from https:// www.edcan.ca/wp-content/uploads/EdCan-2009v49-n3-Masten.pdf

Mota, C. P., \& Matos, P. M. (2010). Adolescentes institucionalizados: O papel das figuras significativas na predição da assertividade, empatia e autocontrolo. Análise Psicológica, 28(2), 245-254. Retrieved from http://www.scielo.mec.pt/pdf/aps/v28n2/ v28n2a01.pdf

Oliveira, A., Matos, A. P., Pinheiro, M. R., \& Oliveira, S. (2015). Confirmatory factor analysis of the Resilience Scale short form in a Portuguese adolescent sample. Procedia, Social and Behavioral Sciences, 165, 260-266. doi: 10.1016/j.sbspro.2014.12.630

Pesce, R. P., Assis, S. G., Santos, N., \& Oliveira, R. V. (2004). Risco e protecção: Em busca de um equilíbrio promotor de resiliência. Psicologia: Teoria e Pesquisa, 20(2), 135-143. doi: 10.1590/S010237722004000200006

Pinheiro, M. R., \& Matos, A. P. (2013). Exploring the construct validity of the two versions of the Resilience Scale in a Portuguese adolescent sample. The European Journal of Social \& Behavioural Sciences, 2(2), 178-189. doi: 10.15405/FutureAcademy/ ejsbs(2301-2218).2012.2.5 
Poletto, M., \& Koller, S. H. (2008). Contextos ecológicos: Promotores de resiliência, factores de risco e proteção. Estudos de Psicologia, 25(3), 405-416. doi: 10.1590/S0103-166X2008000300009

Rutter, M. (1993). Resilience: Some conceptual considerations. Journal of Adolescents Health, 14(8), 626631. doi: 10.1016/1054-139X(93)90196-V

Rutter, M. (2006). The promotion of resilience in the face of adversity. In A. C. Stewart \& J. Dunn (Eds.), Families count: Effects on child and adolescent development (pp. 26-50). Cambridge, NY: Cambridge University Press.

Siqueira, A. C., \& Dell'Aglio, D. D. (2006). O impacto da institucionalização na infância e na ado- lescência: Uma revisão da literatura. Psicologia \& Sociedade, 18(1), 71-80. doi: 10.1590/S010271822006000100010

Wagnild, G. M., \& Young, H. M. (1993). Development and psychometric evaluation of Resilience Scale. Journal of Nursing Measurement, 1(2), 165-178.

Windle, G., Bennett, K., \& Noyes, J. (2011). A methodological review of resilience measurement scales. Health and Quality of Life Outcomes, 9(8), 1-18. doi: 10.1186/1477-7525-9-8

Yunes, M. A., \& Szymanski, H. (2001). Resiliência: Noção, conceitos afins e consideraçôes críticas. In J. Tavares (Org.), Resiliência e educação (pp. 13-42). São Paulo, Brasil: Cortez. 
